\title{
Problems Concerning Women's Participation and Dropout from Self Help Groups in Koraput District of Odisha, India
}

\author{
Moumita Baishya ${ }^{1}$, Ananta Sarkar ${ }^{2}$ and Shivaji Argade ${ }^{3}$
}

${ }^{1}$ Orissa University of Agriculture \& Technology, Bhubaneswar, India

${ }^{2}$ ICAR-Central Institute for Women in Agriculture, Bhubaneswar, India

${ }^{3}$ ICAR-Central Institute of Fisheries Education, Mumbai, India

*Corresponding author

\section{A B S T R A C T}

Self Help Group is a holistic programme of micro-enterprises covering all aspects of selfemployment and organization of the marginalised and weaker section of society especially women.

\section{Keywords}

Problems,

Women, Self Help

Groups, SHGs,

Dropouts

\section{Article Info}

Accepted:

21 May 2020

Available Online:

10 June 2020
The primary data were collected from 200 (SHGs members-100; Non-members-50; Dropout members-50) women respondents from purposively selected Koraput district of Odisha using semistructured interview schedule to identify the problems concerning women's participation and dropout from Self Help Groups. The result shows that lack of transport facilities, long distance of market, lack of training on economic activities, members not attending meetings and no economic activity other than micro lending were major problems faced by the women SHGs members. The lack of transport facilities, lack of training on economic activities, long distance of market and dominance of group leader were the major problems faced by the non-members. The lack of training on economic activities, dominance of group leader, members not giving monthly savings, members not attending regular meetings, no economic activity other than micro lending and less profit from products prepared were major reasons of SHG dropouts. It is suggested that the organisations behind the formation of SHGs should do the review and audit of their financial records to avoid divergence of fund by leader and irregular monthly savings. The rotation of leadership among group members at regular interval, regular training on income generating activities by government organisations or NGOs and improvement in transportation facilities by government will definitely encourage women's active participation in SHGs as well as discourage their dropouts from the SHGs.

\section{Introduction}

A Self Help Group (SHG) is a voluntary association of 10-20 persons from the homogeneous weaker section of the society with a common interest, formed and managed democratically without any political affiliation. As per the State Sector Report 2018 , Odisha is having $6.8 \%$ of total number of SHGs with seventh rank in the country.
Odisha has about 5, 30, 489 SHGs, collecting savings of 924.78 Crores with credit outstanding of 2262 Crores and 1516.6 Crores loan disbursed upto March 2018.

The Government Organizations like NABARD, Mission Shakti and NonGovernmental Organisations like PRAGATI (Protection of Remote Agency and Guaranteed Action for Tribal Improvement), 
SPREAD (Society for Promoting Rural Education and Development), SERP (Society for Elimination of Rural Poverty) are the front runners in promotion of SHGs in the state of Odisha. In 2009, Mission Shakti found low active participation of women in panchayats. Year wise SHG formation in Koraput district showed that after enforcement of Mission Shakti programme by Odisha Government, about 800 SHGs were formed during the first three years. It reached highest during 20052006, there after year wise decreasing trend of number of SHGs was found (from 1120 to 960). According to NRLM report, Koraput district has the second highest number of SHGs (543) having member count less than five which indicates high drop out of members from SHG. Keeping in view the above mentioned facts, it is pertinent to assess reasons behind women's dropout and not joining self-help groups in Koraput district of Odisha.

\section{Materials and Methods}

The Koraput district of Odisha was selected purposively for the present study. The primary data were collected in randomly selected eight villages (Bandakatra, Mahadeiput, Mastiguda, Kendar, Musaput, Dayanidhiguda, Upar Mangra and Doliamb) from Koraput block of Koraput district from randomly selected 200 women respondents consisting of 100 SHG members, 50 nonmembers, and 50 SHG dropouts using semistructured interview schedules. The suitable statistical tools viz. descriptive statistics and binary logistic regression models were used for drawing meaningful conclusions.

\section{Results and Discussion}

\section{Profile of the respondents}

The profile analysis shows that most of the SHG members (44\%) and drop out SHG members $(56 \%)$ belonged to the young age group ( $<35$ years) and most of the non-SHG members $(56 \%)$ belonged to the middle age group (35-50 years). This demonstrates that the young women were more enthusiastic towards participation in SHGs but simultaneously their dropout was also more.

This is the major concern and it calls systematic investigation in this regard. The majority $(97 \%)$ of respondents were married, illiterate $(90 \%$ of the SHG members, $84 \%$ of non-member and $96 \%$ of SHG drop out members). The SHG members (75\%) and non-SHG members (64\%) mostly belonged to other backward classes whereas most (64\%) of the dropout members belonged to schedule tribes. Most of the SHG members (71\%) and drop out members (78\%) had major occupation as agriculture, animal husbandry and labour. Most of the non-SHG members (84\%) had occupation as agriculture followed by animal husbandry and labour. Forty-two percent SHG members, forty-six percent nonmembers, fifty-two percent drop out members of the respondents were the marginal farmer and belonged to the male-headed family.

The majority SHG dropout members (54\%) and non-SHG members (50\%) belonged to income group Rs. 10,000-20,000 but SHG members were almost equally distributed in all income groups. The similar results also reported by Ghosh (2012) and Kumar et al., (2018). About 37 percent of SHG members and 40 percent of drop out members were having income more than Rs. 20,000 whereas only 18 percent of non-SHG members belonged to this income group.

Majority $(72 \%)$ of the SHG drop out members and SHG members $(58 \%)$ were motivated to participate in SHGs by NGOs. Business was the main function of most of the active SHGs but more than 50percentof the drop out SHG members had no function other than lending. 
Mostly (74\%) drops out members were not attending the meeting regularly. About 28 percent of SHG respondents were saving money in the SHG for emergency purpose and most of them took loan from SHGs for business purpose. It was also found out that non-SHG members $(72 \%)$ have a very little participation in the decision making process in their families in contrast to that members of SHG (97\%) had more involvement in family decision making. This implies that SHG members are more confident and empowered, which was also reported by Singh (2012).

\section{Problems concerning women's participation and dropout from self-help groups}

Table 1 exhibits the major problems faced by SHG members were lack of transport facilities (99\%), long distance of market $(56 \%)$ and lack of training on economic activities (36\%).

The lack of transport facilities (82\%), lack of training on economic activities or income generating activities (76\%) and long distance of market (64\%) were the major problems faced by non-SHG members.

The lack of training on economic activities (84\%), dominance of leader (74\%), members not giving monthly savings (68\%) and members not attending regular meetings $(66 \%)$ were major reasons behind the dropout of members from SHG. These findings are in line with the findings of Sarap (2010).

\section{Examining the reason for women dropping out from SHGs using logit model}

For examining the reasons for women's not joining and dropping out from SHGs, a number of problems (Table 1) were screened from different literatures and two logistic regression models were developed.
Considering the model, the variables considered are listed below.

\section{Independent/ predictor variables}

The following problems were considered as independent variables

Lacking of transport facilities $(b)=$ Transport facilities are not good for importing or exporting produce.

Low price and profit of product (e) $=$ SHG business is not profitable and price of the produce is very less.

Members working irregular (i) $=$ SHG members are not working regularly and not serious about the group business.

Non-cooperative SHG members $(j)=$ SHG members are not cooperative with other members who wants to join group.

Long distance of market $(\mathrm{k})=$ the market is far from the village or SHG to get proper price for their produce

Workload $(\mathrm{s})=$ after joining SHG additional responsibility and work load increases.

Dominance of leader $(\mathrm{u})=$ Leaders of SHG not sharing any details and taking loan from bank account of group for their personal purpose.

Improper training $(\mathrm{v})=$ Supporting organizations (NGO, ICDS, govt.) are not conducting training for SHG members.

Members not giving monthly savings $(\mathrm{w})=$ SHG members are irregular in monthly saving of group.

Members not attending meetings $(\mathrm{x})=$ SHG members are not attending monthly group meeting.

SHG has no activity apart from micro lending $(y)=$ SHG not running any business apart from taking loan and saving in the SHG bank account.

Members not repaying loan timely $(\mathrm{z})=$ SHG members not repaying loan taken before ending of repayment period. 


\section{Model 1}

\section{Response variable}

Drop out respondent type $=$ the respondent is a drop out SGH member or not (yes or no). 'Yes' response indicates that respondent is a drop out member and 'no' response indicates that respondent is a SHG member. Here Yes is coded as 1 and No is coded as 0 . There were 50 'Yes' responses (Drop out member) and 100 'No' responses (SHG member).

In the first model, it was considered that there might be some effect of s, u, v, w, x, y, z problems faced by the respondent on dropping out from a SHG (means 'Yes' response). As the response variable is binary in nature, binary logistic regression analysis was used to understand the relationship between the independent and dependent variables.

The analysis was performed using PROC LOGISTIC of SAS 9.3 software. The results are described in sequel. Probability value of the estimated Chi-square statistic (127.69) for likelihood ratio test is found to be $<0.05$ indicates Likelihood ratio test is significant at 5 percent level, therefore, the model is considered significant which is better than the base model containing no independent variable (Table 2).

Probability value for Wald Chi-Square statistic for each independent variable shows that problems $\mathrm{u}, \mathrm{v}, \mathrm{w}, \mathrm{y}$ are significant at $10 \%$ level of significance and might affect a member being drop out or not. No evidence is there that drop out respondent type is related to problems s, x, z. Therefore, the nonsignificant effects were dropped from the model and the following modified model was further developed $\log \frac{\mathbf{p}(\text { Yes })}{\mathbf{p}(\text { No })}=$ Intercept $+\mathrm{u}+\mathrm{v}+\mathrm{w}+\mathrm{y}+\boldsymbol{\varepsilon}$

Then, same binary logistic regression analysis performed using SAS program for given data using modified model. It was found that all the problems included in the modified model are significantly contributing for the response at 5 percent level of significance.

Here, the value of $p$-value for all four parameter mentioned above are less than 5 percent level of significance indicating they have significant effect on dropping out of members from SHG group. Parameter estimates and the Wald confidence limits indicates that $2^{\text {nd }}$ level (Yes) of all these four problems Dominance of leader (u), Improper training (v), Members not giving monthly savings (w), SHG has no activity apart from micro lending (y) are the reasons for dropping out from SHG (Table 3). Majority of the reasons of dropping out of women in SHGs is in tandem with the finding reported by Naik and Rodrigues (2017), Ballem et al., (2012) and APMAS (2006). Here, per cent concordant is very high $(95.3 \%)$ and greater than both per cent discordant $(2.9 \%)$ and per cent tied $(1.8 \%)$ indicating that the model is a good fit and relevant.

\section{Model 2}

\section{Response variable}

Non-SHG member $=$ the respondent was nonSHG member or not (yes or no). 'Yes' response indicates that respondent was a nonSHG member and 'no' response indicates that respondent was not a SHG member. There were 50 'Yes' responses (Non-member) and 100 'No’ responses (SHG member). 
Table.1 Problems faced by SHG members, non-members and drop out members

\begin{tabular}{|l|c|c|c|c|c|c|}
\hline \multicolumn{1}{|c|}{ Problems } & \multicolumn{2}{|c|}{$\begin{array}{c}\text { SHG } \\
\text { members }\end{array}$} & \multicolumn{2}{|c|}{$\begin{array}{c}\text { Non-SHG } \\
\text { members }\end{array}$} & \multicolumn{2}{c|}{$\begin{array}{c}\text { SHG Drop } \\
\text { outs }\end{array}$} \\
\cline { 2 - 6 } & $f$ & $\%$ & $f$ & $\%$ & $f$ & $\%$ \\
\hline Difficulty in getting raw materials (a) & 0 & 0 & 0 & 0 & 0 & 0 \\
\hline Lack of transport facilities (b) & $\mathbf{9 9}$ & $\mathbf{9 9}$ & $\mathbf{4 1}$ & $\mathbf{8 2}$ & 2 & 4 \\
\hline Competition for better quality product (c) & 0 & 0 & 0 & 0 & 0 & 0 \\
\hline Lack of local buyer (d) & 0 & 0 & 0 & 0 & 0 & 0 \\
\hline Less profit from products prepared (e) & 14 & 14 & 14 & 28 & 17 & 34 \\
\hline Loans not received in time (f) & 7 & 7 & 0 & 0 & 2 & 4 \\
\hline High rate of interest (g) & 0 & 0 & 0 & 0 & 0 & 0 \\
\hline Non-availability of common work shed (h) & 0 & 0 & 0 & 0 & 0 & 0 \\
\hline Members working irregular (i) & 14 & 14 & 9 & 18 & 11 & 22 \\
\hline Non-cooperative SHG members (j) & 0 & 0 & 0 & 0 & 6 & 12 \\
\hline Long distance of market (k) & 56 & 56 & 32 & 64 & 0 & 0 \\
\hline Stuff did not approach (l) & 0 & 0 & 5 & 10 & 0 & 0 \\
\hline Newly married members (m) & 0 & 0 & 2 & 4 & 4 & 8 \\
\hline Not allowing by male member (n) & 0 & 0 & 0 & 0 & 0 & 0 \\
\hline Distance from SHG /bank (o) & 2 & 2 & 0 & 0 & 0 & 0 \\
\hline Migration (p) & 0 & 0 & 0 & 0 & 4 & 8 \\
\hline Lengthy documentation (q) & 0 & 0 & 0 & 0 & 0 & 0 \\
\hline Defaulter (r) & 3 & 3 & 0 & 0 & 0 & 0 \\
\hline Work load (s) & 28 & 28 & 14 & 28 & 8 & 16 \\
\hline Lack of awareness about SHG (t) & 0 & 0 & 0 & 0 & 0 & 0 \\
\hline Dominance of group leader (u) & 5 & 5 & 18 & 36 & 37 & 74 \\
\hline Lackof training on economic activities (v) & 36 & 36 & 38 & 76 & $\mathbf{4 2}$ & $\mathbf{8 4}$ \\
\hline Members not giving monthly savings (w) & 5 & 5 & 0 & 0 & 34 & 68 \\
\hline Members not attending regular meetings (x) & 33 & 33 & 0 & 0 & 33 & 66 \\
\hline Noeconomic activity other than micro lending (y) & 27 & 27 & 8 & 16 & 18 & 36 \\
\hline Members not repay loan timely (z) & 0 & 0 & 2 & 4 & 15 & 30 \\
\hline Note: f -Frequency and \%- Percentage & & & & & & \\
\hline
\end{tabular}

Table.2 Probability values of effects of different problems considered

\begin{tabular}{|l|c|c|c|c|c|c|c|}
\hline \multicolumn{1}{|c|}{ Effect } & s & u & v & w & x & y & z \\
\hline Wald Chi-square & 2.08 & 25.48 & 4.22 & 3.59 & 0.01 & 6.03 & 0.03 \\
\hline Pr $>$ ChiSq & 0.14 & $<\mathbf{0 . 0 0 0 1}$ & $\mathbf{0 . 0 4 0 1}$ & $\mathbf{0 . 0 5 8 2}$ & 0.9409 & $\mathbf{0 . 0 1 4 1}$ & 0.8526 \\
\hline
\end{tabular}


Table.3 Parameter estimates, statistics, p-values and confidence limits for modified model 1

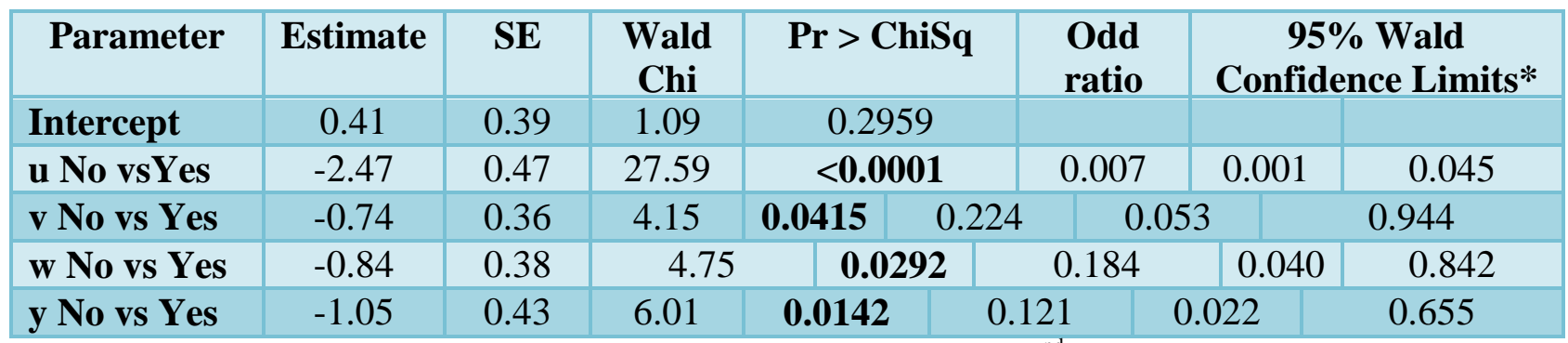

*Value of odds ratio less than 1 and Wald CL not containing 1 indicates that $2^{\text {nd }}$ level of the parameter is more likely

Table.4 Parameter estimates, statistics, p-values and confidence limits of the modified model 2

\begin{tabular}{|l|l|l|l|l|l|l|l|}
\hline Parameter & Estimate & $\begin{array}{c}\text { Standard } \\
\text { Error }\end{array}$ & $\begin{array}{c}\text { Wald Chi- } \\
\text { Square }\end{array}$ & Pr > ChiSq & $\begin{array}{c}\text { Odd } \\
\text { ratio } \\
\text { estimate }\end{array}$ & $\begin{array}{c}\text { 95\% Wald } \\
\text { Confidence Limits }\end{array}$ \\
\hline Intercept & 1.5003 & 0.7516 & 3.9842 & $\mathbf{0 . 0 4 5 9}$ & & & \\
\hline $\begin{array}{l}\text { b No vs } \\
\text { Yes }\end{array}$ & 1.6254 & 0.7713 & 4.4417 & $\mathbf{0 . 0 3 5 1}$ & 25.813 & 1.256 & 530.681 \\
\hline $\begin{array}{l}\text { eNo vs } \\
\text { Yes }\end{array}$ & -0.9132 & 0.3249 & 7.8999 & $\mathbf{0 . 0 0 4 9}$ & 0.161 & 0.045 & 0.575 \\
\hline $\begin{array}{l}\text { kNo vs } \\
\text { Yes }\end{array}$ & -0.9051 & 0.2802 & 10.4334 & $\mathbf{0 . 0 0 1 2}$ & 0.164 & 0.055 & 0.491 \\
\hline $\begin{array}{l}\text { u No vs } \\
\text { Yes }\end{array}$ & -0.9138 & 0.3777 & 5.8537 & $\mathbf{0 . 0 1 5 5}$ & 0.161 & 0.037 & 0.707 \\
\hline $\begin{array}{l}\text { vNo vs } \\
\text { Yes }\end{array}$ & -1.2302 & 0.2573 & 22.8618 & $<\mathbf{0 . 0 0 0 1}$ & 0.085 & 0.031 & 0.234 \\
\hline
\end{tabular}

For the second model, it was considered that there might be effect of $b, e, i, j, k, s, u, v, w$, $\mathrm{x}, \mathrm{y}, \mathrm{z}$ problems on not joining SHG. Probability value for Wald Chi-Square statistics showed that problems b, e, k, u, v are significant at $10 \%$ level of significant and might affect a respondent being non-SHG member or not. Therefore, the model was further modified as

$\log \frac{\mathbf{p}(\text { Yes })}{\mathbf{p ( N o )}}=$ Intercept $+b+e+k+u+v+\varepsilon$

It is clear from the above model that, lack of transport facilities (b), low price and profit of product (e), long distance of market (k), dominance of leader $(\mathrm{u})$, improper training (v)are problems which significantly contributing for the response at 5\% level of significance, indicating presence of those are the reasons for not joining SHG (Table 4). Percent concordant was found to be high $(79.5 \%)$ and greater than both percent discordant and percent tied indicating that the model is a good fit and relevant.

SHGs have been successful in certain extent in developing many rural areas. It has not only provided entrepreneurial opportunities to the people but also has undertaken many activities for the development of rural areas. This study identified the problems concerning women's participation and dropout from Self Help Groups in Koraput district of Odisha. The lack of transport facilities, long distance market, lack of training on economic 
activities, members not attending meetings and no economic activity other than micro lending; lack of transport facilities, lack of training on economic activities, long distance of market and dominance of group leader; lack of training on economic activities, dominance of group leader, members not giving monthly savings, members not attending regular meetings, no economic activity other than micro lending and less profit from products prepared were major concerns of women SHG members, nonmembers and dropouts, respectively. The regular review and audit of financial records, rotation of leadership among group members at regular interval, regular training on different income generating activities by government organisations or NGOs and improvement in transportation facilities by government will definitely encourage women's active participation in SHGs as well as discourage their dropouts from the SHGs.

\section{References}

Andhra Pradesh Mahila Abhivruddhi Society (APMAS). 2006. Self Help Groups in India- A study of the lights and shades, EDA rural system private limited.

Ballem, A., Ghiyazuddin, M. A. and Venkata,
N. A. 2012. Why do people not join or drop out of SHGs? Micro Save (Marketled solutions for financial services), Offices across Asia, Africa and Latin America.

Ghosh, M. 2012. Microfinance and rural poverty, liberalization, growth and regional disparities in India. Springer, 1: 167-184.

Kumar, R., Suar, D. and Mishra, P.2018. Characteristics for the effectiveness of women's Self-Help Groups in Bihar. International Journal of Voluntary and Non-profit Organizations, 29(6): 12831299.

Naik, M. and Rodrigues, A. 2017. Women empowerment through Self Help Groups, realities and challenges. IOSR Journal of Humanities and Social Science, 22(6): 01-09.

Sarap, A. 2010. Group functioning and group stability- A micro level study from rural Orissa. Journal of the Centre for Microfinance Research, II(1): 123-139.

Singh, R. 2012. Women entrepreneurship issues, challenges and empowerment through Self Help Groups- An overview of Himachal Pradesh. International Journal of Democratic and Development Studies, 1(1): 45-58.

\section{How to cite this article:}

Moumita Baishya, Ananta Sarkar and Shivaji Argade. 2020. Problems Concerning Women's Participation and Dropout from Self Help Groups in Koraput District of Odisha, India. Int.J.Curr.Microbiol.App.Sci. 9(06): 3180-3186. doi: https://doi.org/10.20546/ijcmas.2020.906.380 